\title{
DOES PROFITABILITY REFLECT COMPANY'S FINANCIAL HEALTH IN THE REPUBLIC OF SERBIA?
}

\author{
Vladimir Mirković ${ }^{1 *}$ \\ Marija Vujičić', \\ Dragana Andonović Brmalj]
}

${ }^{1}$ Economists Association of Belgrade, Belgrade, Serbia

${ }^{2}$ Third Basic Court,

Belgrade, Serbia
Correspondence:

Vladimir Mirković

e-mail:

vladamirkovic@orion.rs

\begin{abstract}
:
By using quantitative models, it is possible to take insight into real financial strength and creditworthiness of companies. The aim of this paper is to determine if relationship between profitability and financial "health" of companies could be explained through implementation of Kralicek's DF model. The main research question in the paper is defined as follows: are the best performances according to Kralicek's test based on adequate and sustainable proportion of accompanied financial ratios? Authors concluded that the company "HIP Petrohemija" was the best performer among analyzed sample and consequently that company was the subject of comprehensive analysis, using well-known quantitative models such as: Beneish M-score and Altman Z-score. At the end of in-depth analysis, authors unexpectedly identified that profitability of the company "HIP Petrohemija" is direct consequence of government's intervention and conversion of company's debt into the equity. Nevertheless, this conclusion does not diminish the role and value of applied quantitative models in the process of financial health evaluation.
\end{abstract}

Keywords:

financial health, quantitative models, ratio analysis, creditworthiness, Republic of Serbia.

\section{INTRODUCTION}

Financial statements are the key source for the evaluation of company's creditworthiness. Based on annual financial reports, all stakeholders could take insight into company's financial status and could analyze the key performance indicators. There are various models, based on prediction of early warning signals, which could point out the existence of distress in the company's business.

Initial works are related to studies of Beaver (1966) and Altman (1968). This early phase of creditworthiness evaluation based on business indicators led to evolution of contemporary models. Among modern contributions, the most quoted are those from Scott (1981), who stated that financial distress not necessarily leads to bankruptcy and permanent insolvency, while Pastena and Ruland (1986) point out other possibilities for companies in financial distress, such as: business continuity followed by realistic expectations of future solvency and merger activities.

Aligned on Altman's Z-score model, during 1990s, Austrian Professor Peter Kralicek developed the so-called Kralicek's DF indicator (DF abbreviated from: discriminatory function), based on the sample of European companies on the markets in Austria, Germany and Switzerland (Kralicek, 2007; Mizdraković et. al, 2015). Relying on official financial statements, Professor Kralicek carried out a multivariate discriminatory analysis, which resulted in formation of business model for bankruptcy prediction (Zenzerović, \& Peruško, 2006).

The aim of this paper is to determine if implementation of Kralicek's DF model could explain relationship between profitability and financial "health" of companies. 


\section{DATA AND METHODOLOGY}

The purpose of the analysis is to isolate the company with the best performances in terms of profitability and indicators according to Kralicek's DF model. Then, the advancer in the observed sample was the subject of detailed analysis, using well-known quantitative models, such as: Beneish M-score and Altman Z-score. By using Beneish $\mathrm{M}$-score, the authors focused on identifying whether financial statements of the advancer were misrepresented, which led to wrong impression about real earning ability of the company. Later, Altman Z-score model was implemented in order to complete analysis and provide an answer to the question: what is the likelihood of company's bankruptcy?
Starting point in this research was identification of 20 companies with the largest net profit after tax reached at the end of 2017, according to the available financial statements published on the official website of Serbian Business Registry. Beside official financial statements, the authors used valid chart of accounts for mapping the positions that are included in calculation of financial indicators embedded into Kralicek's model. Companies from the sample were subject of analysis through Kralicek's quick test and DF model, which required calculation of several indicators. The structure of the sample is presented in Table 1.

Table 1. Top 20 Serbian companies in terms of net profit in 2017

\begin{tabular}{ll}
\hline \multicolumn{1}{c}{ Legal entity short name } & $\begin{array}{c}\text { Net profit after tax in 2017 } \\
\text { (in 000 RSD) }\end{array}$ \\
\hline 1. HIP Petrohemija & $40,455,606$ \\
\hline 2. NIS & $27,790,460$ \\
\hline 3. Srbijagas & $16,723,376$ \\
\hline 4. Telekom Srbija & $14,548,188$ \\
\hline 5. Tigar Tyres & $10,311,332$ \\
\hline 6. Telenor & $9,000,153$ \\
\hline 7. Galenika & $6,463,456$ \\
\hline 8. Beogradske Elektrane & $5,387,558$ \\
\hline 9. Delhaize Serbia & $4,264,433$ \\
\hline 10. Sunoko & $4,047,623$ \\
\hline 11. Imlek & $4,041,958$ \\
\hline 12. Philip Morris & $3,840,206$ \\
\hline 13. Tetra Pak & $3,832,188$ \\
\hline 14. Železnice Srbije & $3,587,217$ \\
\hline 15. Coca-Cola HBC Srbija & $3,471,770$ \\
\hline 16. Elektroprivreda Srbije & $3,396,385$ \\
\hline 17. Aerodrom Nikola Tesla & $3,265,674$ \\
\hline 18. Jugoimport-SDPR & $3,133,648$ \\
\hline 19. Invej & $3,125,134$ \\
\hline 20. Elektromreža Srbije & Segistry $(2018)$ \\
\hline
\end{tabular}

Quick test gives a company's "snapshot" based on four key indicators, which are grouped into two broad categories: the first two indicators (i.e. self-financing coefficient and debt repayment period in years) determine financial stability, while the other two indicators (i.e. total capital viability percentage and cash flow in business income) determine profitability (Polo\&Caca, 2014). Those four indicators are calculated in the following way: 
Self-financing coefficient $\left(\mathbf{K}_{\mathbf{1}}\right)=\frac{\text { capital }}{\text { total liabilities }}$

Debt repayment period in years $\left(\mathbf{K}_{\mathbf{2}}\right)=\frac{\text { total liabilities }- \text { cash }}{\text { net profit }+ \text { depreciation }}(2)$

Total capital viability percentage $\left(\mathbf{K}_{\mathbf{3}}\right)=\frac{\text { EBIT }}{\text { total assets }}$

Cash flow in business income $\left(\mathbf{K}_{\mathbf{4}}\right)=\frac{\text { net profit }+ \text { depreciation }}{\text { operating income }}(4)$

EBIT (Earnings Before Interest and Taxes) in $\mathrm{K}_{3}$ indicator is calculated as the sum of net profit before interest and taxes and interest expenses. After calculation methods of four business indicators, the authors assigned grades in range from 1 (excellent grade) to 5 (worst grade, which reflects insolvency risk), as per defined criterion in Kralicek (2007). Kralicek's DF indicator is represented with next equation (Kralicek, 2007):

$\mathrm{DF}=1.5 \mathrm{X}_{1}+0.08 \mathrm{X}_{2}+10 \mathrm{X}_{3}+5 \mathrm{X}_{4}+0.3 \mathrm{X}_{5}+0.1 \mathrm{X}_{6}$

where:

$\mathrm{X}_{1}=\frac{\text { EBIT }+ \text { depreciation }}{\text { total liabilities }}$

$\mathrm{X}_{2}=\frac{\text { total assets }}{\text { total liabilities }}$

$\mathrm{X}_{3}=\frac{\text { net profit before tax }}{\text { total assets }}$

$$
\begin{aligned}
& \mathrm{X}_{4}=\frac{\text { net profit before tax }}{\text { total revenues }} \\
& \mathrm{X}_{5}=\frac{\text { inventories }}{\text { total revenues }} \\
& \mathrm{X}_{6}=\frac{\text { operating income }}{\text { total assets }}
\end{aligned}
$$

According to the obtained values of DF indicator, the authors carried out the evaluation of financial strength using defined thresholds presented in Table 2.

Table 2. Kralicek's DF indicator - values and grades

\begin{tabular}{cc}
\hline DF value indicator & Financial stability \\
\hline$>3$ & Excellent \\
\hline 2.2 & Very good \\
\hline 1.5 & Good \\
\hline$>1$ & Medium \\
\hline 0.3 & Bad \\
\hline$\leq 0.3$ & Beginning of insolvency \\
\hline$\leq 0$ & Moderate insolvency \\
\hline$\leq-1$ & Strong insolvency \\
\hline \multicolumn{2}{c}{ Source: Kralicek (2007) }
\end{tabular}

Source: Kralicek (2007)

\section{RESEARCH RESULTS}

The authors conducted quick test based on company's financial statements at the end of 2017 and compared the achieved results with relevant quick test results based on data in 2016 and 2015 (presented in Table 3).

Table 3. Kralicek's Quick test results on sample

\begin{tabular}{lllll}
\hline \multicolumn{1}{c}{ Legal entity short name } & Size & 2017 & 2016 & 2015 \\
\hline 1. HIP Petrohemija & large & 1.00 & 3.50 & 2.50 \\
\hline 2. NIS & large & 1.75 & 2.00 & 3.50 \\
\hline 3. Srbijagas & large & 2.50 & 1.50 & 1.50 \\
\hline 4. Telekom Srbija & large & 1.50 & 1.25 \\
\hline 5. Tigar Tyres & large & 1.00 & 1.00 \\
\hline 6. Telenor & large & 1.00 & 1.00 & 3.25 \\
\hline 7. Galenika & large & 1.75 & 3.50 & 1.75 \\
\hline 8. Beogradske Elektrane & large & 1.50 & 1.00 & 1.75 \\
\hline 9. Delhaize Serbia & large & 1.75 & 1.75 & 1.50 \\
\hline 10. Sunoko & large & 1.50 & 1.00 & 2.25 \\
\hline 11. Imlek & large & 2.75 & 2.00 & 1.75 \\
\hline 12. Philip Morris & large & 1.00 & 1.00 & 1.00 \\
\hline 13. Tetra Pak & large & 1.00 & 2.75 & 4.25 \\
\hline 14. Železnice Srbije & middle & 2.50 & 1.00 & \\
\hline
\end{tabular}




\begin{tabular}{lllll}
\hline 15. Coca-Cola HBC Srbija & large & 1.00 & 1.00 & 1.00 \\
\hline 16. Elektroprivreda Srbije & large & 2.25 & 2.00 & 2.25 \\
\hline 17. Aerodrom Nikola Tesla & large & 1.25 & 1.25 & 1.00 \\
\hline 18. Jugoimport-SDPR & large & 2.00 & 1.50 & 2.00 \\
\hline 19. Invej & small & 2.50 & 4.00 & 2.25 \\
\hline 20. Elektromreža Srbije & large & 2.00 & 2.25 & 2.75 \\
\hline
\end{tabular}

Source: Authors' calculation

Results in Table 3 showed that in 2017 joint stock company "Imlek" had the worst performance (with 2.75), followed by three companies with average grade 2.50, namely: "Železnice Srbije", "Srbijagas" and "Invej”. The prevailing size of organizations in the sample were large companies ( $90 \%$ of them), while small and middle-sized companies participated with $5 \%$ in the observed sample. According to the quick test, average grade for large companies was 1.58 , while small and middle companies had an equal grade of 2.50 .
Considering the legal form of companies, the structure of sample is following: ten companies are organized as joint stock companies, six companies are organized as limited liability companies and four companies are public entities. The best average grade in terms of Kralicek's quick test, observing only legal form of organizations, has the segment of limited liability companies (1.21), followed by the segment of joint stock companies (1.80), while public companies segment has the worst performance (2.06). The worst performers, independent on their legal form, are presented in Figure 1 with black colored marks.

Figure 1. Quick test results in 2017

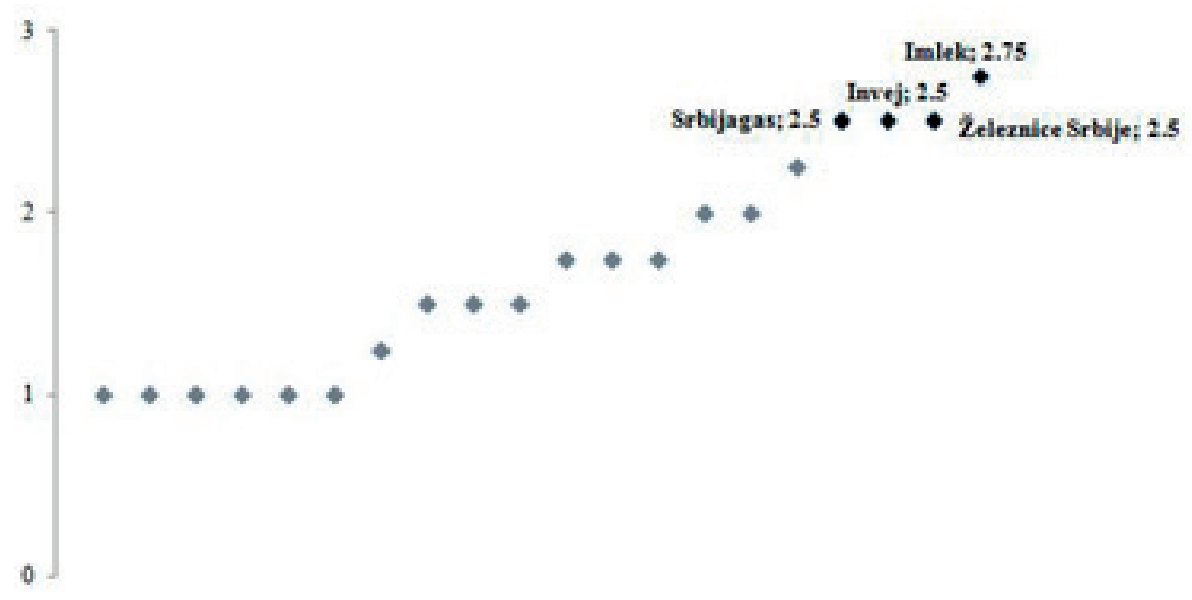

Source: Authors' calculations

The next stage in analysis is related to the implementation of Kralicek's DF indicator, based on equation (5), on the observed sample of companies and comparing results in three consecutive years, for period from 2015 to 2017 (presented in Table 4). 
Table 4. Kralicek's DF indicator on observed sample

\begin{tabular}{|c|c|c|c|c|}
\hline Legal entity short name & Size & DF Indicator 2017 & DF Indicator 2016 & DF Indicator 2015 \\
\hline 1. HIP Petrohemija & Large & 38.82 & 0.10 & 0.12 \\
\hline 2. NIS & Large & 2.36 & 1.50 & 1.54 \\
\hline 3. Srbijagas & Large & 2.42 & 0.45 & 0.52 \\
\hline 4. Telekom Srbija & Large & 2.83 & 2.81 & 2.64 \\
\hline 5. Tigar Tyres & Large & 3.51 & 2.68 & 3.29 \\
\hline 6. Telenor & Large & 5.36 & 5.19 & 4.92 \\
\hline 7. Galenika & Large & 7.01 & 0.20 & 0.24 \\
\hline 8. Beogradske Elektrane & Large & 2.78 & 4.56 & 2.07 \\
\hline 9. Delhaize Serbia & Large & 1.51 & 0.84 & 1.24 \\
\hline 10. Sunoko & Large & 3.54 & 4.06 & 3.26 \\
\hline 11. Imlek & Large & 1.84 & 1.25 & 0.53 \\
\hline 12. Philip Morris & Large & 4.75 & 2.77 & 1.97 \\
\hline 13. Tetra Pak & Large & 8.05 & 6.10 & 8.04 \\
\hline 14. Železnice Srbije & Middle & 4.91 & 2.56 & 0.05 \\
\hline 15. Coca-Cola HBC Srbija & Large & 4.15 & 4.25 & 3.35 \\
\hline 16. Elektroprivreda Srbije & Large & 0.75 & 1.10 & 1.09 \\
\hline 17. Aerodrom Nikola Tesla & Large & 8.40 & 6.67 & 7.10 \\
\hline 18. Jugoimport-SDPR & Large & 2.25 & 2.77 & 1.86 \\
\hline 19. Invej & Small & 9.55 & 0.13 & 4.27 \\
\hline 20. Elektromreža Srbije & Large & 1.85 & 1.13 & 1.56 \\
\hline
\end{tabular}

Source: Authors' calculation

Figure 2 presents results of Kralicek's DF indicator in 2017 for observed sample. Public company "Elektroprivreda Srbije" had the worst performances with indicator 0.75 (black colored mark on Figure 2).
On the other hand, the best performer in the observed sample of companies was joint stock company "HIP Petrohemija" with average grade 38.82 (white colored mark in upper right corner on Figure 2).

Figure 2. Kralicek's DF indicator results in 2017

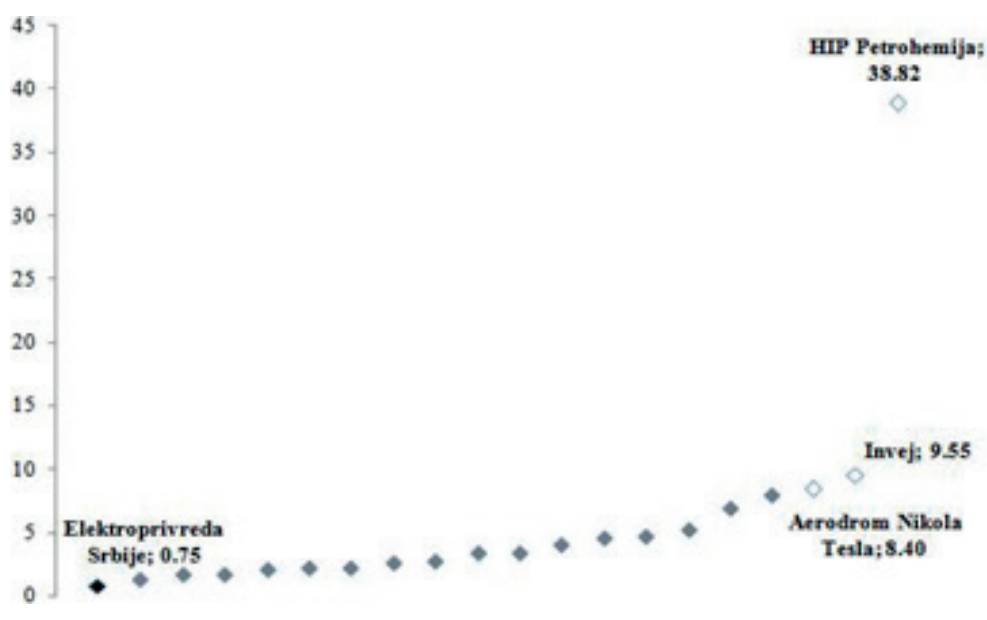


Additional verification of obtained results is conducted via IBM software Statistical Package for the Social Sciences, known as SPSS. Pearson's r coefficient between net profit after tax and Quick test results (-0.207) show that there is a weak inverse correlation between those two variables, confirming the previous assumption that companies with higher net profitability tend to have lower Quick test result. Similarly, Pearson's r coefficient between net profit after tax and DF indicator values (0.683) show that there is a strong positive correlation between those two variables, justifying the assumption that companies with higher net profitability tend to have higher values of DF indicator. The described relationships between variables are presented in Table 5, as well as in Figure 3 and Figure 4 with scatter plot diagrams.

Table 5. Pearson's correlation coefficient $(N=20)$

\begin{tabular}{lccc}
\hline & Net profit after tax 2017 & Quick test & DF indicator \\
\hline Pearson Correlation & 1 & -0.207 & $0.683^{* *}$ \\
\hline Significance (2-tailed) & & 0.38 & 0.001 \\
\hline
\end{tabular}

${ }^{* *}$ Correlation is significant at the 0.01 level (2-tailed)

Source: Authors' calculation

Figure 3. Scatter plot diagram between net profit and Quick test

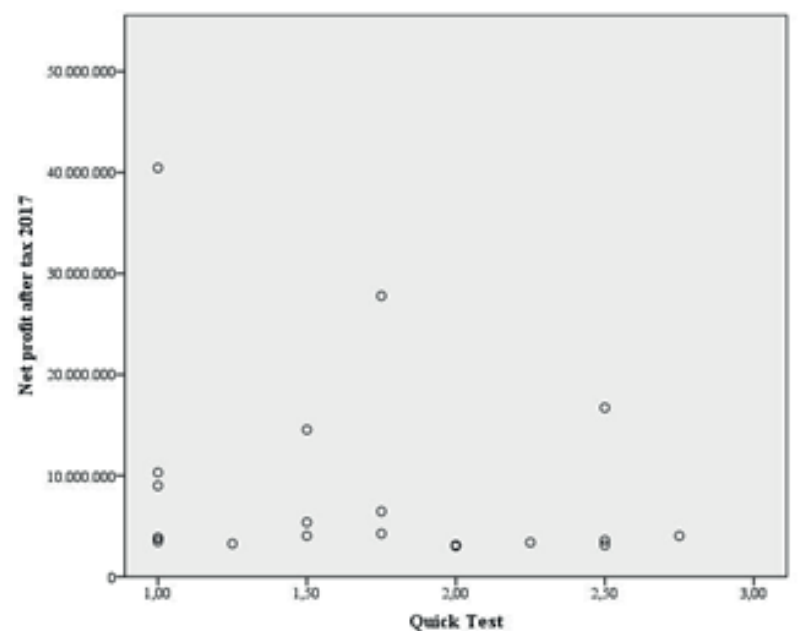

Source: Authors' calculations based on SPSS

Figure 4. Scatter plot diagram between net profit and DF indicator

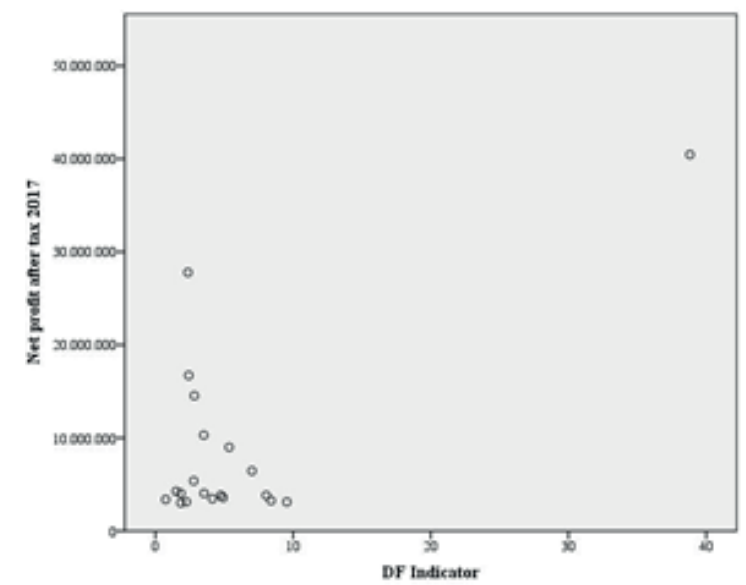

Source: Authors' calculations based on SPSS 
Undoubtedly, the results of Kralicek's DF indicator point out the conclusion that company "HIP Petrohemija" is the main advancer in the sample of 20 companies, initially created by criterion of net profitability. Also, it is obvious that the company "HIP Petrohemija" has the largest differences in final grades according to DF indicator: from 0.12 and 0.10 in 2015 and 2016 respectively, to 38.82 in 2017. The above mentioned results which separate the company "HIP Petrohemija" as the advancer, impose the necessity for detailed analysis, using well-known quantitative models, such as: Beneish M-score and Altman Z-score.

\section{APPLICATION OF BENEISH M-SCORE MODEL}

Professor Messod Beneish introduced multivariate models for the recognition of manipulations in financial statements. Those models are known as Beneish M-score model with five and eight variables, depending on the number of variables that are included in model.
The example of company listed on stock exchange in emerging countries which is exposed to testing and implementation of Beneish M-score model is represented in the paper of Mirković (2014). Mirković concluded that apart from the proscribed liability for joint stock companies to operate transparently and the fact that some of them are among very liquid on Belgrade Stock Exchange, there is a high probability that they potentially misrepresent financial statements. In this paper, the authors implemented the Beneish M-score model for the company "HIP Petrohemija", which is marked as the best performer after the implementation of Kralicek's DF indicator (presented in Table 6) and compared results with defined thresholds for Beneish model. Thresholds are set at minus 2.2 (for Beneish M-score with five variables) and minus 1.78 (for Beneish M-score with eight variables).

Table 6. Beneish M-score model for "HIP Petrohemija"

\begin{tabular}{cc}
\hline Indicator & 2017 \\
\hline DSRI (Days' sales in receivable index) & 1.20 \\
\hline GMI (Gross margin index) & 1.00 \\
\hline AQI (Asset quality index) & 0.00 \\
\hline SGI (Sales growth index) & 2.04 \\
\hline DEPI (Depreciation index) & 1.08 \\
\hline SGAI (Sales and general and administrative & 1.19 \\
\hline expenses index) & 0.52 \\
\hline LVGI (Leverage index) & 0.03 \\
\hline M-SCORE (with 5 variables) & -2.60 \\
\hline M-SCORE (with 8 variables) & 0.94 \\
\hline
\end{tabular}

Source: Authors' calculation

Limitation in the model for the company "HIP Petrohemija" is reflected into the fact that zero value is assigned for one variable (asset quality index), due to non-existence of the balance on financial position "Intangible assets". In respect of the mentioned limitation, the obtained result for Beneish $\mathrm{M}$-score with five variables at minus 2.60 shows that there are no visible drivers that the company "HIP Petrohemija" could be observed as a manipulator. On the other side, result for Beneish M-score with eight variables at 0.94 (both presented in Table 6) show that there is a very high likelihood for financial statements misrepresentation in case of the company "HIP Petrohemija". That conclusion leads to the necessity for complementary analysis using Altman Z-score.

\section{APPLICATION OF ALTMAN Z-SCORE MODEL}

As it is prescribed with original Altman Z-scoring model (Mirković, 2013), the purpose of the model is to evaluate the probability of bankruptcy according to defined variables. Results for original and adjusted Altman Z-scoring applied in the case of the company "HIP Petrohemija" for 2016 and 2017 are showed in Table 7. 
Table 7. Original and adjusted Altman Z-score model for "HIP Petrohemija"

\begin{tabular}{ccc}
\hline Indicator & 2017 & 2016 \\
\hline $\mathrm{T}_{1}=$ Net working capital /Total assets & 0.55 & -2.30 \\
\hline $\mathrm{T}_{2}=$ Retained earnings/ Total assets & 0.13 & 0.00 \\
\hline $\mathrm{T}_{3}=\mathrm{EBIT} /$ Total assets & 0.18 & 0.30 \\
\hline $\mathrm{T}_{4}=$ Book value of equity/Total liabilities & 7.96 & 0.00 \\
\hline $\mathrm{T}_{5}=$ Operational income/ Total assets & 1.36 & 1.60 \\
\hline Original Z-SCORE & 7.58 & $-\mathbf{0 . 1 8}$ \\
\hline Adjusted Z-SCORE & 16.86 & -9.86
\end{tabular}

Source: Authors' calculation

As per Altman Z-score, companies with Z score above 3 are considered as successful and "healthy", the analyzed company "HIP Petrohemija" in 2017 achieved Z-score significantly above the proscribed threshold. This means that business operations of the company are not exposed to risk considering key indicators covered by Altman Zscore model. The largest contribution to reached Z-score in 2017 has indicator T4 (equals 7.96), which is the result of increasing the capital level which stood at 2.4 billion RSD in 2017 (Serbian Business Registry, 2018).

By analyzing audit report for 2017, it could be concluded that the bankruptcy proceeding under the company "HIP Petrohemija" was initiated in August 2017, after the adoption of reorganization plan. By government involvement and debt conversion into the capital through a new issue of shares, "HIP Petrohemija" was artificially enabled to reach positive net result of 40.46 billion RSD in 2017. Government intervention in the case of "HIP Petrohemija" is clearly justified in the ownership structure of the company. Namely, among five largest shareholders are state-owned enitites or entities which are closely connected to the state, such as: "Srbijagas" - 32.2\% of shares, "Republic of Serbia" - 30\% of shares, "NIS" $20.9 \%$ of shares, "Elektroprivreda Srbije" - $4.9 \%$ of shares and "Development Fund Republic of Serbia" - 4.4\% of shares (Central securities depository and clearing house, 2018). Moreover, according to the information from the company "HIP Petrohemija" website "The creditors have converted $52.3 \%$ of total claims, while $47.7 \%$ have been written-off, so the issue of the old debts has been solved. After the adoption and implementation of reorganization plan, the Republic of Serbia and connected entities own about $76 \%$ of shares, while "NIS" and "Lukoil" possess the remaining 24\% of shares" (HIP Petrohemija, 2017).

Due to specific characteristics of emerging markets in comparison to developed economies, original Altman Zscore is adjusted for the purpose of reflecting the differences among markets. The adjusted Z-score for emerging economies should be calculated as follows:
$\mathrm{Z}=3.25+6.56 \mathrm{~T}_{1}+3.26 \mathrm{~T}_{2}+6.72 \mathrm{~T}_{3}+1.05 \mathrm{~T}_{4}$

In the above mentioned formula, four variables which are used are the same as it was already described via original Z-score (Table 7), while the fifth variable from the original Z-score model is omitted due to Altman's observation that variable $\mathrm{T}_{5}$ showed the largest deviation for certain industries (Vlaović Begović et al., 2014). The achieved values of Z-score for emerging markets are interpreted in the following manner:

1. Z-score higher than 2.60 means that the company is in "safe" zone;

2. Z-score between 1.10 and 2.60 means that the company is in "grey" zone;

3. Z-score at the level lower than 1.10: the company is in "distress" zone.

Analyzing the company "HIP Petrohemija" authors founded that the adjusted Z-score (calculated and presented in Table 8) in 2017 outperformed the original Z-score, contributing to the conclusion that relation between observed ratios could be assessed as favourable. Also, this conclusion should be complemented with the fact that government intervened in the case of the company "HIP Petrohemija" in order to save the company from bankruptcy. It was clearly recorded in official audit report for 2017 and the results of Altman Z-score in 2016 (both original and adjusted), when all relevant parameters signalized that bankruptcy of the company "HIP Petrohemija" was inevitable. 


\section{CONCLUSION}

As the fourth industrial revolution is focused on the automation of traditional industrial practices, the financial industry will also change its form in many aspects. In that sense, the area which sholud be more or less modified in the future is the usage of quantitative models in more sophisticated manner. This paper highlights the usage of quantitative models for the identification of company's real financial strength. The authors assessed the financial health of 20 companies which reached the largest net profit after tax in 2017, by using Kralicek's Quick test and DF indicator. After the evaluation by Kralicek's models, the authors chose the company with the best performances and exposed it to the rigorous and "indepth" analysis via Altman Z-score and Beneish Mscore models. Kralicek's Quick test and DF indicator showed that the best performances were related to joint stock company "HIP Petrohemija". Simultaneously, that company was the company with the highest net profit after tax recorded in 2017.

In the second phase, the authors made detailed analysis regarding financial strength of the company "HIP Petrohemija", using Altman Z-score and Beneish M-score models. Despite the fact that company "HIP Petrohemija" has recorded the highest net profit after tax in 2017, it is clear that reached net profit is the result of government intervention and conversion of company's debt into the equity. Reorganization plan implemented in consolidation process of the company "HIP Petrohemija" with high involvement of the Serbian Government was the major driver of the highest net profit after tax in 2017. The case of the company "HIP Petrohemija" is very specific, where the state as the largest individual shareholder used its discretion right to convert debt into equity and prevent further loss generation in this joint-stock company.

In the context of paper title, the authors found that profitability should be considered as one of important determinants for the evaluation of company's financial health. But at the same time, analysts should take into account all other aspects which are hidden behind the reached profitability, meaning that the achieved net profit does not necessarily rely on operating performances of the company.

The above mentioned does not diminish the role of quantitative models in the economic theory and practice. On the contrary, quantitative models are very useful and should be used as basic as well as additional tool for comprehensive analysis and evaluation of company's financial health.
Also, quantitative models are very important from the aspect of automation process in creditworthiness evaluation in the future and they should be treated as the area which needs continuous upgrade as a part of lifelong learning concept.

\section{LITERATURE}

Altman, E. I. (1968). Financial ratios, discriminant analysis and the prediction of corporate bankruptcy. Journal of Finance, 589-609.

Beaver, W. H. (1966). Financial ratios as predictors of failure. Journal of Accounting Research, 71 - 111.

Central securities depository and clearing house (2018). Available at: http://www.crhov.rs/?Opcija=1\&odabraniemite $\mathrm{ntjmb}=1 \mathrm{BD} 3 \mathrm{CBD} 2 \mathrm{C} 9 \mathrm{D} 8 \mathrm{D} 6 \mathrm{DC} \& \mathrm{sin}=79 \mathrm{~B} 8 \mathrm{ABACB} 8 \mathrm{~A}$ 6A3D4D5E8FEE2 (17.07.2020)

HIP Petrohemija (2017). Available at: http://www.hip-petrohemija.com/press/news/adopted-new-pre-packedreorganization-plan--hip-petrohemija-without-outstanding-debts.n-608.198.html?offset $=0$ \&newsPage $=488$ (17.07.2020)

Kralicek, P. (2007). Ertrags und Vermogensanalyse (QuickTest). Available at: www.kralicek.at/pdf/qr-druck.pdf(17.07.2020)

Mirković, V. (2013). Altmanov Z-skoring model za predviđanje bankrota preduzeća na primeru kompanije "Telefonija a.d. Beograd". In SYM-OP-IS 2013 (XL Simpozijum o operacionim istraživanjima), pp. 117-122. Zlatibor: Faculty of Organizational Sciences.

Mirković, V. (2014). Beneish M-skoring model: studija slučaja preduzeća "Jedinstvo a.d. Sevojno". In FINIZ 2014 The Role of Financial Reporting in Corporate Governance, pp. 135-137. Belgrade: Singidunum University, Serbia.

Mizdraković, V., Knežević, G. \& Stanić, N. (2015). Bankruptcy risk exposure of Serbian hotels in the period 2008-2012. In SITCON 2015 - Singidunum International Tourism Conference, pp. 164-167. Belgrade: Singidunum University.

Pastena, V., \& Ruland, W. (1986). The Merger/Bankruptcy Alternative. The Accounting Review, 288-301.

Polo, A., \& Caca E. (2014). Kralicek QuickTest - An Analysis Tool for Economics Units Determination in Liability Difficulty. European Scientific Journal, 142-152.

Scott, J. (1981). The probability of bankruptcy: A comparison of empirical predictions and theoretical models. Journal of Banking \& Finance, 317-344.

Serbian Business Registry (2018). Available at: http://www.apr. gov.rs/eng/Home.aspx (17.07.2020)

Vlaović Begović S., Momčilović M. \& Tomašević, S. (2014). Ocena kreditnog boniteta preduzeća Z-score modelom. Ekonomske teme, 193-204

Zenzerović, R., \& Peruško, T. (2006). Kratki osvrt na modele za predviđanja stečaja. Ekonomska istraživanja, 132-151. 